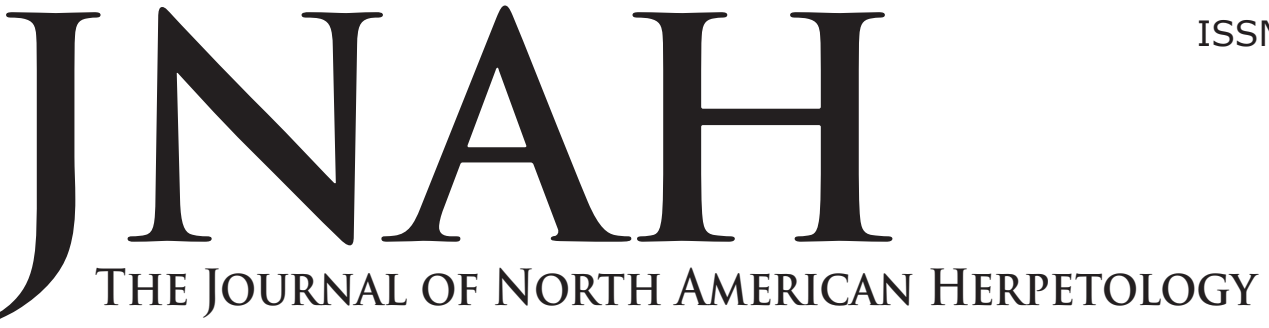

ISSN 2333-0694

Volume 2020, Number 1

23 March 2020

journals.ku.edu/jnah

\title{
AMPHIBIAN DISTRIBUTION IN THE GEORGIA SEA ISLANDS: IMPLICATIONS FROM THE PAST AND FOR THE FUTURE
}

\author{
NANCY K. O'HARE ${ }^{1,3}$, C. RON CARROLL ${ }^{2}$, LAN MU ${ }^{1}$, THOMAS R. JORDAN ${ }^{1}$ \\ ${ }^{1}$ Department of Geography, University of Georgia, Athens, GA 30602 \\ ${ }^{2}$ Odum School of Ecology, University of Georgia, Athens, GA 30602 \\ ${ }^{3}$ CORRESPONDENCE: email nancyohare@gmail.com
}

\begin{abstract}
We summarized amphibian distributions for 12 coastal islands in Georgia, USA. Occurrence among islands was correlated with life history traits, habitats, island size, distance to other islands, and island geological age. Species' distributions were determined from published literature. Island sizes and vegetation types were derived from 2011 Georgia Department of Natural Resources habitat maps, which included both federal and state vegetation classification systems. Species occurring on more islands tended to have greater total reproductive output (i.e., life span $>4$ years, and annual egg production $>1,000$ eggs) and adults had tolerance of brackish environs. Larger islands had greater area of freshwater wetlands, predominantly short hydroperiod ( $<6$ months). Species tied to long hydroperiod wetlands ( $>6$ months) were more restricted in their distribution across islands. Overall, larger islands supported more species, but the correlation was weaker for geologically younger Holocene islands (age $<11,000$ years). While Euclidean distance between islands does not necessarily preclude inter-island dispersal, inhospitable habitat for amphibians (brackish tidal marshes and creeks interspersed with wide rivers) suggests that inter-island dispersal is very limited. The paucity of recent occurrence data for amphibians in this dynamic coastal region, let alone standardized annual monitoring data, hinders efforts to model species' vulnerability in a region susceptible to sea level rise and development pressure. The most common survey method, standardized amphibian vocal surveys, will detect Anuran reproductive efforts, but is unlikely to ascertain if breeding was successful or to detect salamanders. While it will not replace actual population data, consideration of critical life-history traits and breeding habitat availability can be used to direct management to support long-term species persistence in changing environs. Even common amphibians in coastal conservation areas of Georgia are vulnerable to increasing population isolation caused by unsuitable habitat.
\end{abstract}

Key Words: Biogeography, Land-use legacies, Amphibians

INTRODUCTION

The Southeastern Coastal Plain of the United States of America (USA) has been suggested as an unrecognized hotspot of floral and faunal biodiversity (Noss et al., 2014). Yet basic knowledge is still lacking for present-day species richness, diversity, and natural population fluctuations within the region. Consequently, the impacts of future anthropogenic influences-including climate change-on species distribution are difficult to determine. How can potential future changes be addressed if present-day species richness, diversity and natural population fluctuations along geographic gradients are unknown? Determining species richness and diversity for areas already in public or private conservation should be a priority, since these areas are less likely to have future direct anthropogenic influences related to development.
In the Georgia Sea Islands region (Zeigler, 1959; Gibson, 1948; Figure 1), local patterns of amphibian distribution and persistence relate to both physical geography and species' life history traits. The outermost islands varying in distance from the mainland between 3 and $15 \mathrm{~km}$. These outer islands are geologically the oldest and were once part of the mainland. Between the outer islands and the mainland is an intricate system of tidal creeks, salt marshes, and numerous marsh islands created within the past 10,000 to 12,000 years by sedimentation (Gibson, 1948).

Life-history traits of import include habitat preferences, breeding strategy, and intolerance of brackish water. The 25 species of Class Amphibia documented on the adjacent mainland (17 native Anura and eight Caudata) have diverse habitat preferences. Adults of three anuran 
species live in wetlands; adults of four species are arboreal near the natal wetlands; and adults of ten species live in xeric to mesic uplands, but typically return to natal wetlands to breed. The eight caudates in the region have more variable relationships with freshwater wetlands for breeding and adult habitat. Three genera live and reproduce entirely in mesic uplands (Desmognathus, Eurycea (two species), Plethodon), without need for freshwater ponds. The adults of one genus (Ambystoma) live in mesic uplands but require freshwater for breeding. Two fully aquatic genera are tied to wetlands, but survive drydowns by aestivation (Siren, Amphiuma). There is one genus, Notophthalmus, with environmental plasticity in life-history within the species, but its life history in the region has not been described. Most amphibians have explosive breeding capacity during favorable conditions, allowing them to persist even after significant habitat changes (Gagne and Fahrig, 2010; Vitt and Caldwell, 2014). Persistence in an area is likely linked to annual reproductive effort as well as total reproductive potential, which is related to life span. In this region, species' annual reproductive effort per female varies from $<50$ eggs to thousands of eggs per annum (Wright, 1932), and life span varies from approximately 2 to 15 years (Snider and Bowler, 1992). The Georgia Sea Islands are surrounded by tidal rivers and salt marsh. Most amphibians are prone to desiccation when exposed to brackish and salty water. However, in coastal regions they may adapt either behaviorally or physiologically to reduce desiccation (Neill, 1958; Rogell et al., 2011).

The Georgia Sea Islands also have an extensive landuse history spanning the past 250 years (Coulter, 1955; Vanstory, 1970). Several of the larger islands in the region have been completely developed (Sea Island, Wilmington), possibly limiting connections among islands. Others have been partially developed (Tybee, Jekyll, Isle of Hope, Cumberland, Skidaway) with the remainder of the island protected as public lands. Land-use history includes logging, clearing for agriculture, plowing, livestock, and digging drainage ditches. These activities may have occurred simultaneously or discretely.

It is impossible to determine historical amphibian distribution; consequently, it is difficult to estimate what has changed on the islands due to recent human influence. Determining current species richness and distribution in the region has its own challenges. Many of the museum records include a specific locale (Williamson and Moulis, 1979, 1994), but also pre-date extensive regional and on-island developments of the last 30 years. More recent work tended to generalize to the county level rather than specific locales (Dorcas and Gibbons, 2008; Jensen et al., 2008). There have been a few recent short-term trapping efforts on the Georgia coast (Tuberville et al., 2005; Dodd and Barichivich, 2007; O'Hare and Madden, 2017). The National Park Service Southeast Coast Monitoring Network recently established amphibian monitoring protocols for the three federal park service units in the region (Byrne et al., 2010a, b; Byrne et al., 2011). However similar efforts are lacking for most of the islands.

Two previous studies considered herpetofaunal biogeography of the Georgia Sea Islands. Laerm et al. (2000) related species diversity of selected islands to geological age (Pleistocene versus Holocene), island size, distance to the mainland, and qualitative assessments of sampling effort and development. They found significant correlation of species diversity with geological age, island size, and sampling effort. However, they did not test whether island age was related to island size, nor did they include quantitative habitat variables such as the wetland area. Shoop and Ruckdeshcel (2003) proposed an alternative causal factor related to meta-population dynamics. The outer islands with a Pleistocene core were presumed to have similar fauna as the mainland before their isolation by sea level rise during the warming Pleistocene-Holocene transition 10,000 to 12,000 years before present. Their present-day fauna was presumed to have resulted from island-specific extinction events. The Holocene islands were formed by sedimentation in the past $\sim 11,000$ years from freshwater river discharge between the mainland and the now isolated outer ridge forming present-day Pleistocene-core islands. Species present on these newly formed Holocene islands represent successful colonization. However, Shoop and Ruckdeshcel (2003) did not investigate whether there were patterns to extinction or colonization or offer any geographic analyses. The perspectives of both Laerm et al. (2000) and Shoop and Ruckdeshcel (2003) on amphibian diversity overlooked physical geographical factors and species-specific life-history traits likely to influence amphibian richness on islands in the region.

This study contributes to the existing knowledge of amphibian biogeography of the Georgia Sea Islands by considering both physical geography and life-history traits. We predict that: 1 ) species occurring across more islands have greater total reproductive output (longer life span, greater number of eggs laid per year), shorter aquatic developmental stage, and adults that tolerate brackish water; 2) larger islands, regardless of geological age, will support higher species richness; 3 ) species tied to longer hydroperiod habitats ( 6 to 12 months) have restricted present-day distribution; and 4) dispersal between outer islands is limited by unfavorable habitat (e.g., wide rivers) rather than the physical Euclidean distance between islands.

\section{MATERIALS AND METHODS}

\section{Study Area}

The study area consists of 12 islands of coastal Georgia, USA for which information on amphibian diversity exists and at least part of the island has private conservation easement or is public lands at either the state or federal level (see Figure 1; Table 1). It includes widely recognized areas such as Cumberland National Seashore, as well as smaller, regionally known areas such as Wormsloe State Historic Site, Ossabaw Island, and Wassaw National Wildlife Refuge. Most, if not all, of these 12 islands were former antebellum cotton or rice plantations (Vanstory, 1970). Upland areas were typically logged or cleared for agriculture and freshwater wetlands were drained or hydrologically manipulated by construction of drainage ditches. Secondary forests have regrown in island upland areas over the past century.

\section{Amphibian Species Richness and Life History Traits}

Species presence/absence for each island was determined from published literature, which included compilation of museum specimens, incidental observations, and standardized surveys (Williamson and Moulis, 1979, 1994; Laerm et al., 2000; Shoop and Ruckdeshcel, 2000; Shoop and Ruckdeshcel, 2003; Tuberville et al., 2005; Byrne et al., 2010a, b; Byrne et al., 2011; O'Hare and Madden, 2017). We excluded species for which a museum record or occurrence was disputed and was the only record of occurrence of a species on the island. Life history traits were also determined from the litera- 


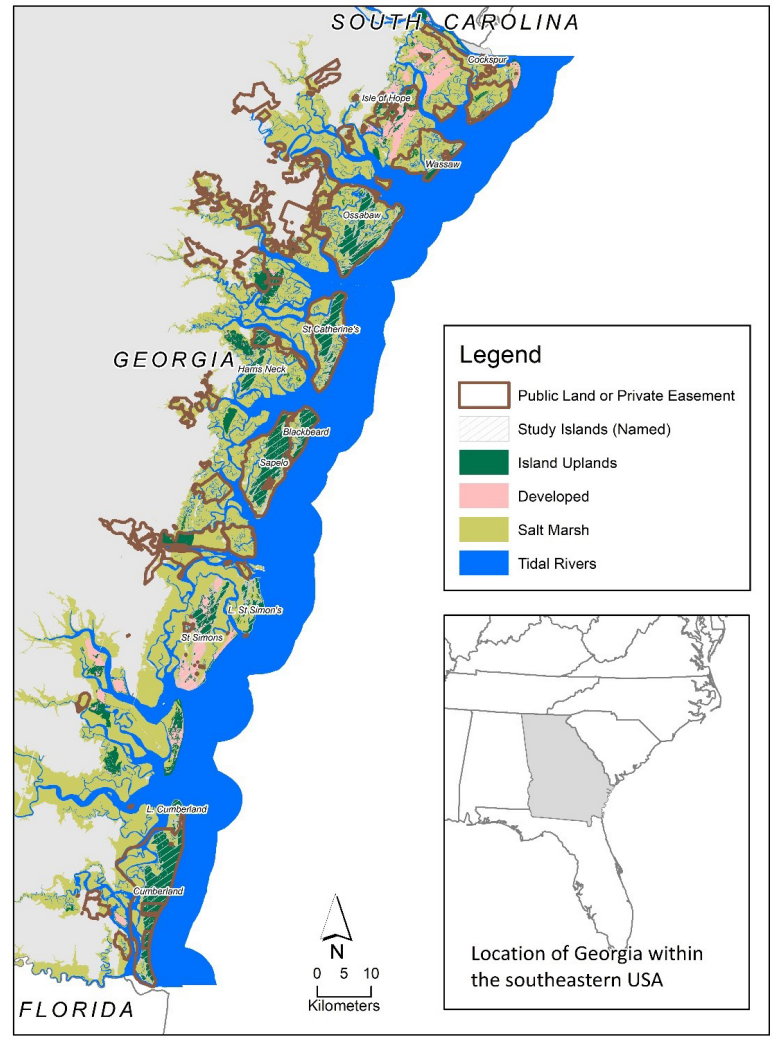

Figure 1. Study area location. Islands included in the study are named. Note that public lands frequently included the island as well as adjacent marsh habitat. ture. Traits included life span (Snider and Bowler, 1992), breeding season, clutch size, and length of larval stage (Wright, 1932; Dorcas and Gibbons, 2008), and tolerance for brackish water (Neill, 1958; Christman, 1974). Distribution and life history traits were analyzed to determine correlations with landscape variables.

\section{Landscape Characterization and Linkages}

Landscape characteristics were linked to the databases of amphibian species distribution and life history traits. The number and location of islands were derived from the Georgia Department of National Resources (GA DNR) digital vector vegetation maps at 1:3,000 scale (available http://data.geospatial.org) (Georgia Department Natural Resources, 2010). The maps were derived from 2009 and 2010 U.S. Department of Agriculture National Agricultural Imagery Program (NAIP) 1-m digital aerial imagery. Vegetation communities were classified according to the State Wildlife Action Plan (SWAP) classification for Georgia (Association of Wildlife Associations, 2012). We created a geographic information system (GIS) layer of island outlines by querying the GA DNR vegetation maps for non-estuarine or brackish land covers. Contiguous polygons were dissolved to obtain island outlines, with the transportation linkages between islands clipped at the island edges. The SWAP categories were simplified even further to "wetland", "upland", and "developed". The SWAP "wetland" habitats were characterized as short ( $<6$ months) or long ( $>6$ months) hydroperiod based upon dominant vegetation. SWAP also classifies some upland communities as successional, which we used as indicators of substantial land-use history (e.g., clear cutting).

To investigate linkages between islands, two raster data layers were created at a final resolution of $10-\mathrm{m}$ pixel size for the entire Georgia Sea Islands region (180 km

Table 1. List of islands and the conservation area on the island. Only two islands (Isle of Hope and St. Simon's) are partially in conservation. GA DNR = Georgia Department of Natural Resources. NWR $=$ National Wildlife Refuge. NERR $=$ National Estuarine Research Reserve. $\mathrm{NM}=$ National Monument. NS = National Seashore. SHS = State Historic Site.

\begin{tabular}{|c|c|c|c|c|c|c|}
\hline Age & Island & Site Name & Agency & Area $(\mathrm{Ha})$ & Percent Natural & $\begin{array}{c}\text { Percent } \\
\text { Conserve }\end{array}$ \\
\hline \multicolumn{7}{|c|}{ Holocene } \\
\hline & Cockspur & Fort Pulaski NM & NPS & 121 & 94 & 100 \\
\hline & Wassaw & NWR & USFWS & 760 & 99 & 100 \\
\hline & L. St. Simon's & & Private & 1239 & 100 & 100 \\
\hline & Blackbeard & NWR & USFWS & 1427 & 97 & 100 \\
\hline & L. Cumberland & NS & NPS & 531 & 98 & 100 \\
\hline & Isle of Hope & Wormsloe SHS & DNR & 630 & 51 & 51 \\
\hline & Harris Neck & NWR & USFWS & 1644 & 90 & \\
\hline \multicolumn{7}{|c|}{ Pleistocene Core } \\
\hline & St. Catherine's & & Private & 2674 & 98 & 100 \\
\hline & Ossabaw & & Private & 4021 & 97 & 100 \\
\hline & Sapelo & NERR/Private & $\begin{array}{c}\text { NOAA, DNR, } \\
\text { Private }\end{array}$ & 4083 & 94 & \\
\hline & St. Simon's & $\begin{array}{l}\text { Fort Frederica } \\
\text { NM }\end{array}$ & NPS & 4816 & 37 & \\
\hline & Cumberland & NS & NPS & 6371 & 96 & \\
\hline
\end{tabular}


north-south and 10 to $20 \mathrm{~km}$ east-west). The first was simply a Euclidean distance (nearest neighbor) matrix from the island outline to each adjacent island created at $10 \mathrm{~m}$. The second raster was derived from the GA DNR habitat map to create a cost resistance surface from habitat suitability (Adriaensen et al., 2003). The habitat map was first converted to raster format with a 1-m cell size, with pixels anchored to the $10 \mathrm{~m}$ grid of Euclidean distance, so that the smaller tidal creeks separating islands would be represented in the cost resistance surface. Natural freshwater and upland cells were assigned a relative cost of 1 , development, pine plantations and other agriculture, a cost of 2, tidal brackish and salt marshes a cost of 3 , tidal creeks and rivers a cost of 4 . The $1-\mathrm{m}$ raster was up-sampled to a $10-\mathrm{m}$ raster, with resultant cost distance raster cells assigned the sum of the $1-\mathrm{m}$ raster input values. This method preserved contributions of finer scale features more so than categorization based upon the dominant feature in a $10 \mathrm{~m}$ grid cell size. Both the Eucliean distance and cost resistance surfaces were symbolized using values related to amphibian travel distances derived from the literature (e.g., $<1 \mathrm{~km}, 1$ to 2.5 $\mathrm{km},>2.5$ to $5 \mathrm{~km},>5$ to $10 \mathrm{~km},>10$ to $25 \mathrm{~km}$, and more than $25 \mathrm{~km}$ ). Less than $1 \mathrm{~km}$ would be typical within population migration between adult and breeding habitats for many species. Less than $5 \mathrm{~km}$ covers both within and between population dispersal by most species. Higher values represent decreasing likelihood of dispersal, with anything beyond $25 \mathrm{~km}$ rare and random chance.

\section{Software and Statistical Analyses}

We used ArcGIS 10.2 (ESRI, Inc.) for GIS analyses (e.g., feature extraction from existing layers, spatial joining of layers). Species accumulation curves and estimates of maximum species richness were produced using EstimateS 9.1.0 for Windows (Colwell and Elsensohn, 2014). Scatterplots and statistical analyses were performed in Statistica 12 (StatSoft, 2014). Correlation between species richness, life-history traits, and landscape variables were tested using the non-parametric Spearman R for correlation due to relatively small and unequal sample sizes; significance was interpreted for $p$ values less than 0.05 .

\section{Species Richness}

Twenty-three amphibian species (16 anurans and seven caudates; Table 2) occurred across the 12 islands. The highest species richness (19) was recorded from the largest island, Cumberland Island. Four species occurred on all 12 islands, with a fifth species occurred on 11 of the 12 islands. Ten species occurred on three or fewer islands. No species were endemic. There were three additional species (Acris crepitans (Northern Cricket Frog), Anaxyrus quercicus (Oak Toad), and Eurycea cirrigera (Southern Two-lined Salamander)) present on the mainland, but their occurrence on the islands is disputed by Shoop and Ruckdeschel (2003).

Correlates of Species Richness: Island Size, Landscape Metrics, and Life History Traits

Each of the 12 study islands were greater than 100 ha. There were another 37 islands greater than 100 ha for which species information were not available; 2 islands have private conservation easements with minimal development and the remaining 35 are partially to completely developed.
The size of islands which are either public lands or private conservation easements ranged between 121 ha and 6,371 ha, with an average size of 4,287 ha. The cores of five of these 12 islands were formed during the Pleistocene Epoch with additional area accreted during the Holocene; the remaining seven were entirely formed during the more recent Holocene. The older Pleistocene core islands were larger (mean 4,326 ha \pm 62.4 standard error (se), $n=5$ ) than Holocene islands ( $n=7$; mean 1065 hat 18 se; ANOVA, df =1, 9, $F=16.4$; $p<0.001$ ). There was no overlap in size; the smallest Pleistocene island (St. Catherine's, 2,673 ha) was $\sim 1,000$ ha larger than the largest Holocene island (Harris Neck, 1,643 ha). For 10 of the 12 islands included in this study, the entire island was either public land or private conservation easement and development was less than 10 percent of the island area. The first exception was the Isle of Hope; Wormsloe State Historic Site occupies the southern portion of the island and the northern 48 percent of the island is residential development, primarily single-family homes with density of $\sim 3$ houses per acre, with most of the residential development occurring since the 1950s. The second exception was Fort Frederica on St Simon's Island, which represents 1 percent of the island, with the remaining portion developed as residential or urban areas.

Larger islands supported greater species richness (Spearman R $=0.822$; Table 3, Figure 2). Correlation was relatively higher for geologically older islands compared to younger islands (i.e., Spearman $\mathrm{R}=0.648$ for Pleistocene and 0.171 for Holocene islands). Species persisting on Pleistocene islands also tended to colonize a larger number of Holocene islands (Spearman $\mathrm{R}=0.837, \mathrm{p}<$ 0.01 ; Figure 3)

The percentage of GA DNR SWAP communities representing wetland habitats ranged between 0 percent (Cockspur Island) and 21.0 percent (Blackbeard Island), with an average of 6.7 percent wetland habitat per island. Area of wetland habitat was positively correlated with island size (Spearman $\mathrm{R}=0.773$ ). Shorter hydroperiod wetlands were more common than longer hydroperiod wetlands (average of 5 percent vs 1 percent of area, respectively). Area of shorter hydroperiod wetlands was also more strongly correlated with total island area

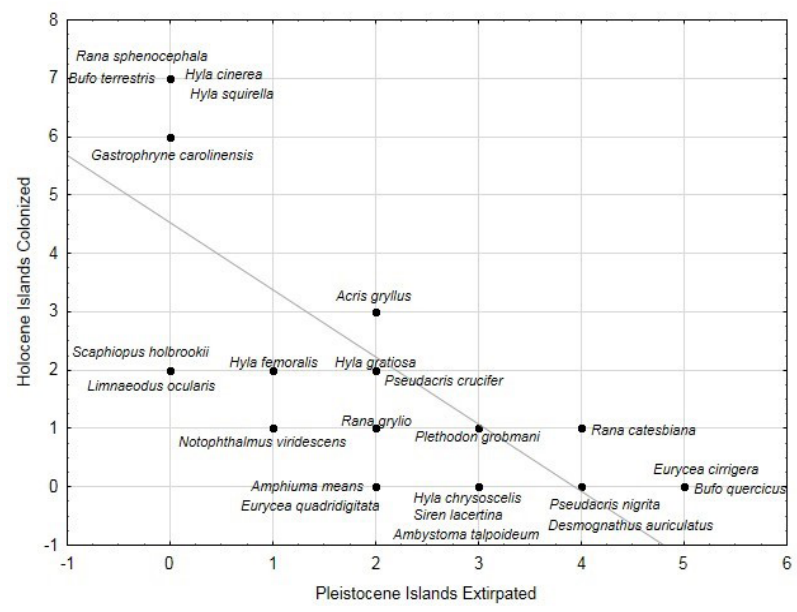

Figure 2. Scatterplot of number of Pleistocene islands species extirpated from (maximum of 5 ) versus number of Holocene islands species colonized (maximum of 7 ). 
Table 2. Number of islands amphibians occurred. Holocene islands would have been colonized following their formation. Pleistocene core islands would have started with the same species as on the mainland; any species currently lacking were extirpated after isolation from the mainland.

\begin{tabular}{|c|c|c|c|}
\hline Species & Total \# Islands & \# of Holocene & \# of Pleistocene \\
\hline \multicolumn{4}{|l|}{ Anurans } \\
\hline Acris crepitans (Northern Cricket Frog) & Disputed & & \\
\hline Acris gryllus (Southern Cricket Frog) & 5 & 3 & 2 \\
\hline Anaxyrus quercicus (Oak Toad) & Disputed & 0 & 5 \\
\hline Anaxyrus terrestris (Southern Toad) & 12 & 7 & 0 \\
\hline Gastrophryne carolinensis (Eastern Narrowmouth Toad) & 11 & 6 & 0 \\
\hline Hyla chrysoscelis (Cope's Gray Treefrog) & 2 & 0 & 4 \\
\hline Hyla cinerea (Green Treefrog) & 12 & 7 & 0 \\
\hline Hyla femoralis (Pine Woods Treefrog) & 6 & 2 & 1 \\
\hline Hyla gratiosa (Barking Treefrog) & 5 & 2 & 2 \\
\hline Hyla squirella (Squirrel Treefrog) & 12 & 7 & 0 \\
\hline Limnaeodus ocularis (Little Grass Frog) & 7 & 2 & 0 \\
\hline Pseudacris crucifer (Spring Peeper) & 4 & 2 & 2 \\
\hline Pseudacris nigrita (Southern Chorus Frog) & 1 & 0 & 4 \\
\hline Lithobates catesbiana (American Bullfrog) & 2 & 1 & 4 \\
\hline Lithobates grylio (Pig Frog) & 4 & 1 & 2 \\
\hline Lithobates sphenocephala (Southern Leopard Frog) & 12 & 7 & 0 \\
\hline Scaphiopus holbrookii (Eastern spadefoot) & 7 & 2 & 0 \\
\hline Eleutherodactylus planirostris (Greenhouse Frog) & 1 & & \\
\hline \multicolumn{4}{|l|}{ Caudates } \\
\hline Ambystoma talpoideum (Mole Salamander) & 2 & 0 & 3 \\
\hline Amphiuma means (Two-toed Amphiuma) & 3 & 0 & 2 \\
\hline Desmognathus auriculatus (Southern Dusky Salamander) & 1 & 0 & 4 \\
\hline Eurycea cirrigera (Southern Two-lined Salamander) & Disputed & 0 & 5 \\
\hline Eurycea quadridigitata (Dwarf Salamander) & 3 & 0 & 2 \\
\hline Notophthalmus viridescens (Eastern Newt) & 5 & 1 & 1 \\
\hline Siren lacertina (Greater Siren) & 1 & 0 & 4 \\
\hline Plethodon glutinosis (Slimy Salamander complex) & 3 & 1 & 3 \\
\hline Total Number of Species & 23 & & \\
\hline Anurans & 16 & & \\
\hline Caudates & 7 & & \\
\hline Disputed & 3 & & \\
\hline
\end{tabular}

(Spearman $\mathrm{R}=0.776$ ) than area of longer hydroperiod wetlands (Spearman $\mathrm{R}=0.585$ ).

All islands had secondary successional forest communities, an indication of past agriculture or logging. The percentage ranged from $<1$ percent (Little St. Simon's Island and Little Cumberland Island, both Holocene islands) to 52 percent (Cockspur Island, also Holocene), with an average of 18.8 percent per island. There was no correlation between percentage successional forest communities and amphibian diversity (Spearman $\mathrm{R}=0.025$ ).

Species that laid greater numbers of eggs occurred on more islands (Spearman $\mathrm{R}=0.594$; Table 4). There was no significant correlation between species distribution and adult longevity, breeding season (winter versus spring-summer), and minimum hydroperiod required for egg and tadpole development. However, scatterplots suggest that species living longer, having shorter aquatic developmental stage ( $<3$ months), and adults with some tolerance of brackish water tend to be more widely distributed (Figure 4).

The Euclidean distances between islands were within the range of long-distance amphibian dispersal (Figure 5 ). The average Euclidean distance of the five nearest neighbors was calculated for each of the study islands. 
Table 3. Spearman rank order correlations between species richness, island area, wetland area (total area, area of long hydroperiod wetlands ( $>6$ months) and area of short hydroperiod wetlands $<6$ months)), percent successional forests and island age (Pleistocene or Holocene). Marked correlations $(*)$ were significant at $p<0.05$.

\begin{tabular}{|c|c|c|c|c|c|c|}
\hline & \multicolumn{6}{|c|}{ Wetland Area } \\
\hline & Island Area & Total & Long & Short & $\begin{array}{c}\text { Percent } \\
\text { Successional }\end{array}$ & Island Age \\
\hline Richness & $0.822 *$ & $0.589 *$ & $0.494 *$ & $0.659 *$ & 0.025 & $0.825^{*}$ \\
\hline Island Area & --- & $0.773 *$ & $0.585^{*}$ & $0.776 *$ & $0.145^{*}$ & $0.864^{*}$ \\
\hline Total Wetland & $0.773 *$ & & & & $-0.156 *$ & $0.469 *$ \\
\hline Long & $0.585^{*}$ & $0.577^{*}$ & & & $-0.211^{*}$ & $0.382 *$ \\
\hline Short & $0.776 *$ & $0.971 *$ & & & $-0.089 *$ & $0.529 *$ \\
\hline
\end{tabular}

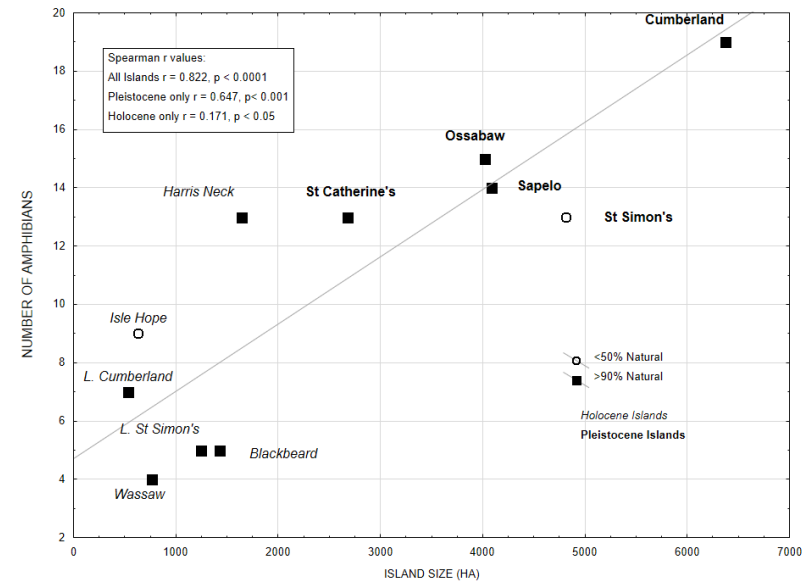

Figure 3. Scatterplots of island size and species richness, coded by percent of island that is currently undeveloped. Harris Neck is the largest Holocene island, and St. Catherine's is the smallest Pleistocene-core island. Development tends to be low to moderate density housing ( 2 to 5 units per acre).

Euclidean distance for first nearest neighbor ranged between $25 \mathrm{~m}$ (Isle of Hope to mainland) and $2.8 \mathrm{~km}$ (Wassaw to Flora Hammock). There was no correlation between island area and Euclidean distance to any nearest neighbor (Spearman $\mathrm{R}=0.130$ for $1^{\text {st }},-0.217$ for $2^{\text {nd }}, 0.035$, for $3^{\text {rd }},-0.025$ for $4^{\text {th }}$, and $0.0185^{\text {th }}$ nearest neighbor, respectively) nor between species richness and Euclidean distance to any nearest neighbor (Spearman $\mathrm{R}=-0.080$ for $1^{\text {st }},-0.181$ for $2^{\text {nd }},-0.140$, for $3^{\text {rd }},-0.113$ for $4^{\text {th }}$, and $-1.1635^{\text {th }}$ nearest neighbor respectively; Figure 6). Overall, Euclidean distance suggested that most outer Pleistocene islands were theoretically connected to each other and to the mainland through inner Holocene islands. The exception was Cumberland Island, which was isolated from all but Little Cumberland Island (Ho-

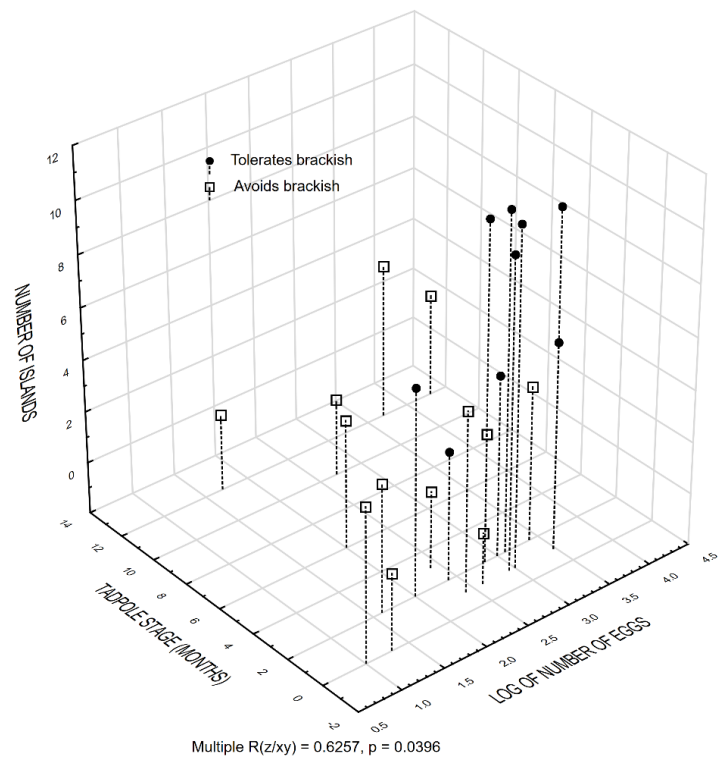

Figure 4. Three-dimensional scatter plot of duration of tadpole stage (e.g. minimum continuous hydroperiod for reproduction; left axis), number of eggs laid per year; right axis), and number of islands upon which amphibian species occurred (vertical axis). Points classified by ability of adults to tolerate brackish water.

locene addition to the Pleistocene core-Cumberland) and the mainland.

Since nearest neighbor distances did not correlate with species richness, we developed a cost resistance surface to incorporate the increased resistance to amphibian travel posed by development, salt marshes and tidal rivers. Tidal rivers, having both current and salinity, are major dispersal barriers for amphibians. The widest divisions were oriented north-south, creating nine basins

Table 4. Spearman Rank correlations of life history traits with occurrence on islands (12 maximum). Breeding season was either winter, spring/summer, or summer/ fall. Egg/Tadpole duration was minimum number of days from egg laying to tadpole metamorphosis. Salinity was ability of adults to tolerate brackish water for short periods, but not breeding in brackish water. Marked correlations $\left({ }^{*}\right)$ were significant at $p<0.05$.

\begin{tabular}{lccccc}
\hline & Longevity & Number Eggs (log) & Breeding Season & $\begin{array}{c}\text { Egg/Tadpole } \\
\text { Duration }\end{array}$ & Salinity \\
\hline \# Islands & 0.105 & $0.594^{*}$ & 0.415 & -0.033 & $0.675^{*}$ \\
Longevity & & 0.115 & 0.150 & -0.044 & 0.262 \\
\hline
\end{tabular}




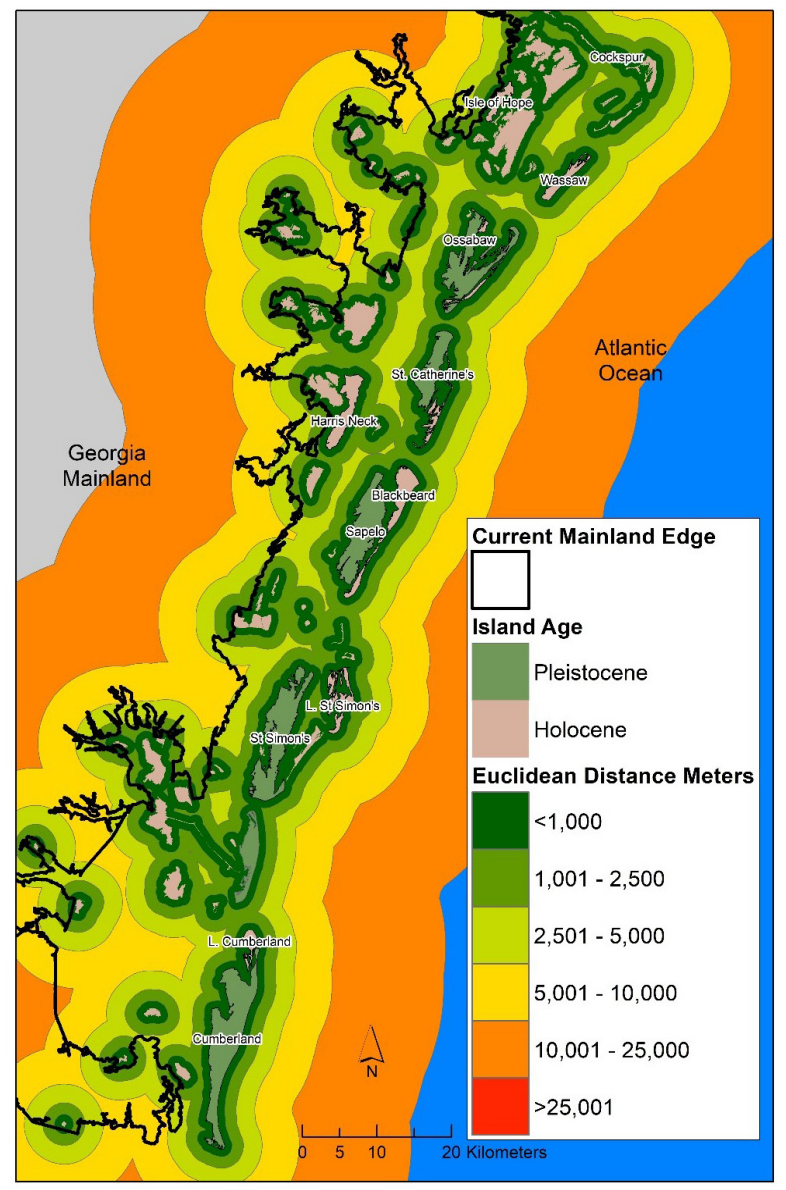

Figure 5. Euclidean (nearest neighbor) distance between islands.

defined by river mouths varying in width between 2 and $5 \mathrm{~km}$. Five of these nine basins had an outer Pleistocene core island (Ossabaw, St Catherine's, Sapelo, St Simon's, Jekyll, Cumberland). Other basins had outer islands formed during the Holocene (Tybee, Wassaw, Wolf). There were smaller east-west divisions demarcated by tidally influenced rivers and creeks of varying widths and depths.

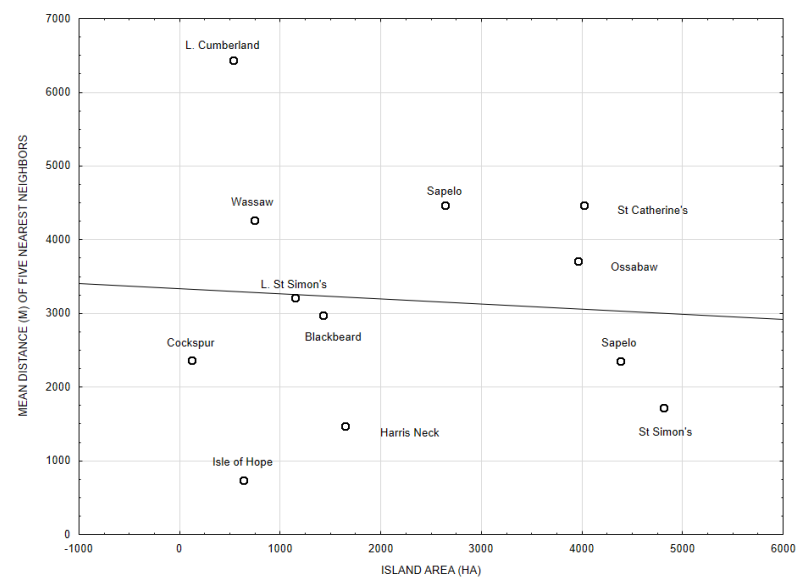

Figure 6. Scatterplot of mean distance between five nearest neighbors and island area in hectares.

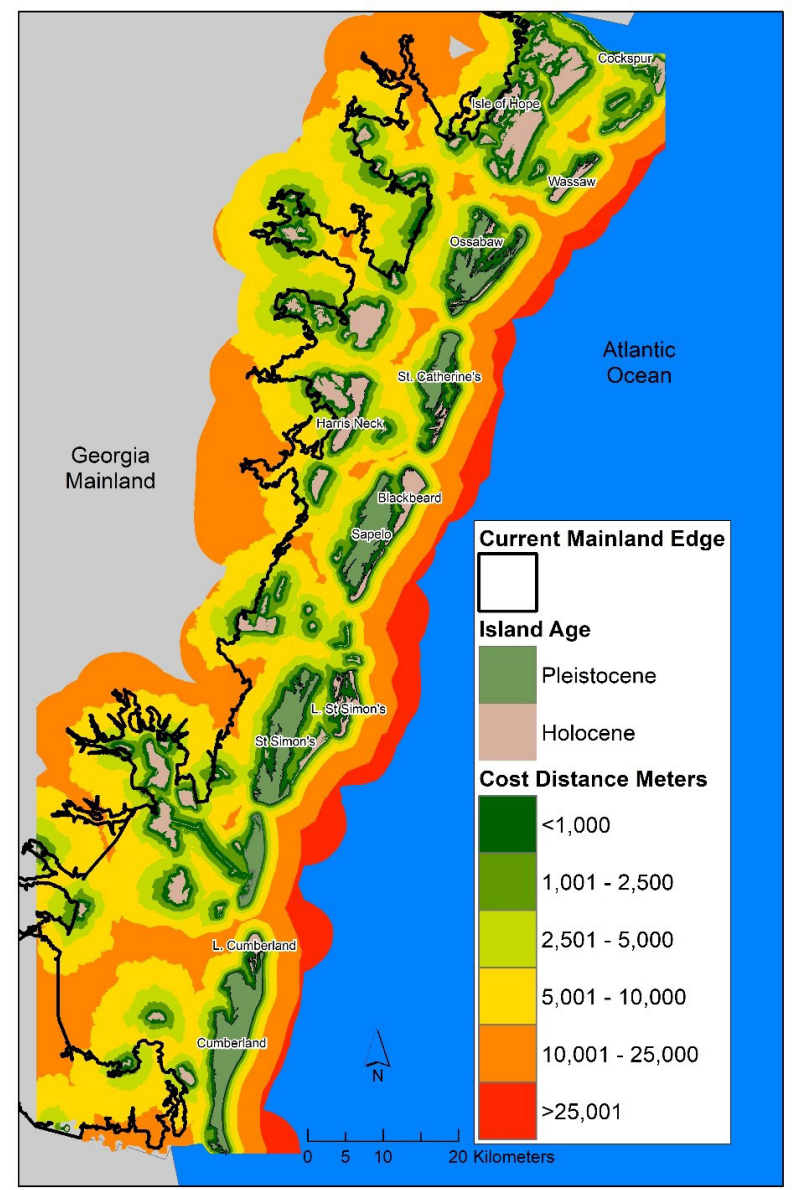

Figure 7. Distance factored by cost to travel across habitat types for the Georgia Sea Islands region.

Cost resistance surface analysis indicates that four of the nine basins identified above are isolated from the mainland and that all outer islands are isolated from each other (Figure 7). Island groups falling between the major rivers may have connectivity to others within the same sub-basin.

\section{DISCUSSION}

A total of 23 amphibian species occurred across the 12 islands included in this study of the Georgia Sea Islands. However, no single island supported all species; species richness on individual islands ranged between 5 and 18 . Species occurring on more islands had larger annual egg production ( $>1,000$ eggs) and adults tended to tolerate brackish water. Larger islands had more wetland area, particularly short hydroperiod wetlands. Species tied to long hydroperiod wetlands ( $>6$ months) were more restricted in their distribution. Overall, larger islands, regardless of geological age, supported greater species richness; the correlation was stronger for geologically older islands. Species which persisted on Pleistocene islands were also more likely to colonize Holocene islands, suggesting that the life history traits for persistence through time were similar to life history traits facilitating colonization of more recently formed Holocene islands.

This study added the first occurrence of the woodland salamander Plethodon glutinosus (slimy salamander complex) to a Holocene island, at Wormsloe State Histor- 
ic Site on the Isle of Hope. Occurrence records for $P . \mathrm{glu}$ tinosus exist for only two of the five Pleistocene-core islands (St Catherine's and Ossabaw). This species is likely to occur on other Holocene and Pleistocene islands. Also, the first occurrence of the non-native Eleutherodactylus planirostris (Greenhouse Frog) (Byrne et al., 2011) was recently documented for any Georgia Sea Island. Regular inventory and monitoring of species is also valuable for detecting early establishment of non-native species, thereby likely to decrease their impact or management costs.

Three species present on the mainland but missing from the islands have disputed occurrences on Pleistocene islands (Acris crepitans, Anaxyrus quercicus, and Eurycea cirrigera). The southern edge of the natural range of Acris crepitans occurs around the Savannah River, the boundary between Georgia and South Carolina, and few undeveloped islands occur in this region. Both $A$. quercicus and E. cirrigera occur throughout coastal Georgia mainland. Eurycea cirrigera tends to favor woodland streams, which are absent from the islands. Suitable habitat for $A$. quercicus exists on the islands. While it has a short developmental stage (30 to 45 days), its overall total reproductive output ( 300 to 500 eggs) and life span of approximately 4 years is relatively less than other species common across the islands. However, Acris gryllus (Southern Cricket Frog) has similar life-history traits and has been verified on three islands by recent trapping. Overall, species occurrence on Pleistocene islands was more similar to the mainland, despite being further distance, while occurrences on Holocene islands were more idiosyncratic, with less clear patterns.

Laerm et al. (2000) suggested that herpetofaunal species diversity in the Georgia Sea Islands region was partly related to island age. Shoop and Ruckdeshcel (2003) suggested that current patterns resulted from differential extirpation on Pleistocene islands whereas patterns on Holocene islands resulted from differential colonization. However, neither of these studies considered landscape characteristics, such as distance between islands or habitats available on islands. Higher correlation of species richness with island size on Pleistocene versus Holocene islands is congruent with both previous studies. Both persistence and colonization should be higher on larger islands, especially if the island is closer to a source population on either the mainland or a Pleistocene-core island. The largest Holocene island, Harris Neck, had the highest species richness (13) of Holocene islands, and was similar in richness to 4 of the 5 Pleistocene islands even though it was $\sim 1,000$ ha less in size than the smallest Pleistocene island. Species that tended to persist on the older, larger Pleistocene islands also colonized a greater number of Holocene islands. Both the mainland and the Pleistocene islands could serve as source for colonization of Holocene islands. However small sample sizes precluded quantitative, statistical analyses.

On small islands, diversity-area relations may shift, in part due to balance between local extirpation and recolonization from adjacent areas (Whitehead and Jones, 1969; Barrett et al., 2003; Triantis et al., 2006; Triantis and Sfenthourakis, 2012). However, the definition of "small island" differs even within a taxonomic group (Triantis et al., 2006; Santos et al., 2010; Triantis and Sfenthourakis, 2012). Each of the islands in the study area exceeded literature definitions of "small". However, many amphibians rely upon micro-habitat features for breeding. Micro-habitat features critical for breeding, e.g. seasonal ponds, are still under-represented in broad scale vegetation mapping, in part because of difficulty of detection and pre-defined minimum mapping units. For example, USFWS National Wetlands Inventory maps typically have a minimum mapping unit of about onehalf hectare, to purposively avoid errors of commission (i.e., the error of including non-wetlands as wetlands) and recognize that small wetlands are likely unmapped in forested areas of the eastern USA (Tiner, 1997). Regional studies tended to rely upon higher resolution aerial photography, but imagery in the USA was frequently acquired during the growing season, so that seasonal ponds in forested areas were difficult to detect. Even the finer scale habitat maps used in this study did not map any wetland habitat on one island for which eight seasonal pond-breeding amphibian species were recently confirmed (Byrne et al., 2011). Consequently, the area of a critical micro-habitat may be as influential as total land area.

The ability to detect the structure of microhabitat wetland features via remote sensing is improving (Burne and Lathrop, 2008; Carpenter et al., 2011). In the past decade, airborne light ranging and detection (LIDAR with point density on the order of one point per square meter has effectively detected small, seasonal freshwater ponds even in forested habitats. While techniques to detect and characterize the structure of seasonal ponds are improving, the ability to tie structure to seasonal hydrology lags. The hydrology of seasonal ponds, especially the depth and duration of inundation, relies upon precipitation which naturally varies temporally and is still difficult to determine without local measurement of water depth and duration (Kish et al., 2012).

Few United States Geological Survey (USGS) gauges monitoring surface water occur on coastal islands (approximately 18) (Peck et al., 2009), and most are clustered in developed areas (Savannah, Jekyll Island) or areas with high industrial water use (Brunswick). Estimated water table map for coastal Georgia described water table as nearly coincident with the ground surface along the coast (Peck and Payne, 2003), creating a freshwater lens. However, anecdotal evidence suggests that surface freshwater is decreasing on several of the Georgia coast islands. At Wormsloe, for example, there is one particular area which exhibits evidence of a previous longer hydroperiod than was observed in the past four years of this study. The small depression currently has $<5$ mature canopy Taxodium distichum (Bald Cypress), numerous cypress knees, yet no seedling or saplings. This species prefers more than a 6-month hydroperiod and seedlings fail to germinate if soil moisture is too low. Between 2010 and 2014, this pond within Wormsloe was never observed to have more than a few continuous weeks of surface water.

Regional development continues and may indirectly alter freshwater resources on public lands and private conservation easements in this region. Given temporal delay in amphibian population change related to their low energetic requirements as r-selected ectotherms, the results of regional development and freshwater withdrawals may take decades to result in local species extirpations (Gagne and Fahrig, 2010). Wetland desiccation has been tied to a decrease in four common amphibians in Yellowstone National Park (McMenamin et al., 2008). Coastal Georgia seems to be experiencing both changes in the surficial, freshwater lens as well as changes in the deeper Floridan aquifer. Artesian wells, supplied 
primarily by the deep Floridan aquifer, no longer flow on Wormsloe, Sapelo, St Catherine's (Nelson et al., 2012) and Ossabaw Islands, and municipal water supplies tapping the Floridan aquifer now require pumping. Artesian wells on the islands likely supplied surficial freshwater wetlands which have become ephemeral as artesian flow decreased (Vance et al., 2010). Since hydrology is a major abiotic factor with regional controls, natural resource managers of individual conservation units need to consider the external threats to their internal management (Kushlan, 1987). Areas with moderate species diversity which are in conservation, such as Wormsloe, should consider resources management to improve breeding habitat to maintain current species richness.

Annual monitoring of amphibian breeding would catalog species persistence and facilitate correlation between population dynamics and changing environs (Ray et al., 2014). Narrower time-windows of either extirpation or colonization would also be possible to determine. Annual amphibian monitoring has recently been implemented at the three federal parks in the region. These surveys included the first record of the non-native Eleutherodactylus planirostris on the islands and confirmed the occurrence of Hyla gratiosa (Barking Treefrog) (Byrne et al., 2009). State conservation lands would benefit from adopting a similar monitoring protocol. In this study, species richness on 7 of the 12 islands was derived from museum vouchers and surveys from $30+$ years prior yet it remains the best available information.

Resources management of regional amphibian populations is challenged by jurisdictional boundaries. The conservation areas included in this study occur in five of the six coastal Georgia counties. Four are privately owned. Two are owned by the State of Georgia and managed by Department of National Resources. Six are in federal ownership, managed by either the National Park Service (three units) or the Fish and Wildlife Service as National Wildlife Refuges (three units). The areas also cross hydrological units (HUC) defined by the USGS. Major rivers tend to be the central feature of a HUC basin (HUC 6). However, these rivers are major dispersal barriers for amphibians and consequently were the edges between dispersal basins. The study area spans 4 basins (HUC6). Smaller rivers or tidal channels further sub-divide basins into sub-basins (HUC8) or watersheds (HUC10). There were 11 watersheds, and watershed boundaries bisected 9 of the 12 islands.

The Georgia Sea Islands developed under fluctuating sea levels during the Pleistocene-Holocene transition (Hoyt, 1967). Predictions for future sea level rise suggest that tidal marshes between the islands are likely to convert to more open water (Craft et al., 2009), further isolating the islands and hindering interisland dispersal by amphibians. The outer islands are the least likely to be completely inundated by future sea level rises since they tend to be higher in elevation and larger in area. Establishing baseline amphibian population data now will facilitate future correlations to changes in island area and connectivity. Any species extirpated from an island is unlikely to re-establish from natural dispersal given that remaining populations tend to be separated by large rivers which are dispersal barriers.

\section{CONCLUSIONS}

We confirmed that species occurring across more islands tended to have greater total reproductive output (longer life span, greater number of eggs), had a short- er tadpole/larval stage, and adults had some tolerance for brackish water, and thereby more likely to disperse across saltwater marshes. Larger islands, regardless of geological age, supported more species. The relationship between geological age and species richness was more idiosyncratic, especially on smaller islands. Larger islands also had larger area of wetland, particularly short-hydroperiod wetlands. Consequently, we were unable to separate the effect of island size, geological age, and habitat (gamma) diversity on amphibian species richness. The area of a critical micro-habitat may be as influential as total land area. Finally, dispersal between outer islands was limited more by between island matrix of tidally-influenced rivers up to $8 \mathrm{~km}$ in width and, or extensive tidal marshes rather than Euclidean distances between islands.

While the Georgia Sea Islands have no endemic species, individual conservation areas should maintain current species richness by supporting existing populations. On some islands, the scarcity of freshwater wetlands to support breeding appears to be a limiting factor. Resource management actions should minimally include annual monitoring of anuran breeding, establishment of surface water gauges on islands, especially those more likely to be influenced by adjacent development or water-intensive land-uses and actions to protect freshwater quality by preventing tidal influx along man-made canals connecting the depressions to adjacent salt marshes. If the surficial freshwater lens has been permanently depleted, then measures to retard percolation of rainfall into soil, such as lining natural depressions, may be useful.

\section{ACKNOWLEDGEMENTS}

This research was supported by a four-year Wormsloe Graduate Fellowship to Nancy O'Hare, funded by the Wormsloe Institute for Environmental History (WIEH) and the University of Georgia (UGA) Graduate School. The WIEH also provided funding for trapping materials, arranged for on-site lodging, and provided a golf cart for on-island travel. Additional support and personal encouragement from Sarah Ross, Craig Barrow, Diana Barrow, and Hunter Anderson are greatly appreciated. Chris Floyd and Jason Allison, Wormsloe State Historic Site managers, contributed additional logistical support. Yanxi Wang and Jingmei Wei assisted with deployment of field equipment. Trapping complied with conditions in Georgia Department of Natural Resources permit 29WJH-13-77, Scientific Research and Collecting Permit for Wormsloe State Historic Site, and University of Georgia Animal Use Permit A2012 060014-Y2-A1. John Crawford, UGA Marine Extension on Skidaway Island, provided valuable feedback on herpetofaunal distribution throughout the region, as well as his recollections of changes since the 1970s, particularly at Wormsloe. Andrea Presotto provided spirited discussions and comments to improve the manuscript. Finally, clarity and conciseness was improved by thoughtful comments from two anonymous reviewers

\section{LITERATURE CITED}

Adriaensen, F., Chardon, J.P., De Blust, G., Swinnen, E., Villalba, S., Gulinck, H. and Matthysen, E. 2003. The application of 'least-cost' modelling as a functional landscape model. Landscape and Urban Planning 64: 233-247.

Association of Wildlife Associations. 2012. Best Practices for State Wildlife Action Plans: Voluntary Guidance 
to States for Revision and Implementation. Available at: http://www.fishwildlife.org. Accessed October 10, 2014.

Barrett, K., Wait, D.A. and Anderson, W.B. 2003. Small island biogeography in the Gulf of California: Lizards, the subsidized island biogeography hypothesis, and the small island effect. Journal of Biogeography 30(10): 1575-1581.

Burne, M.R. and Lathrop, R.G. 2008. Remote and field identification of vernal pools. page 55-68 In Science and Conservation of Vernal Pools in Northeastern North America edited by A.J.K. Calhoun and P.G. Demaynadier. CRC Press.

Byrne, M.W., Elston, L.M., Smrekar, B.D. and Bazemore, P.A. 2010a. Summary of Amphibian Community Monitoring at Cumberland Island Seashore 2009. US Department of Interior, Natural Resource Program Center, Fort Collins, CO.

Byrne, M.W., Elston, L.M., Smrekar, B.D. and Bazemore, P.A. 2010b. Summary of Amphibian Community Monitoring at Fort Frederica National Monument 2009. US Department of Interior, Natural Resource Program Center, Fort Collins, CO.

Byrne, M.W., Smrekar, B.D., Moore, M.N., Harris, C.S. and Blankley, B.A. 2011. Summary of Amphibian Community Monitoring at Fort Pulaski National Monument 2010. US Department of Interior, Natural Resource Program Center, Fort Collins, CO.

Carpenter, L., Stone, J. and Griffin, C.R. 2011. Accuracy of aerial photography for locating seasonal (vernal) pools in Massachusetts. Wetlands 31: 573-581.

Christman, S.P. 1974. Geographic variation for salt water tolerance in the frog Rana sphenocephala. Copeia 1974: 773-778.

Colwell, R.K. and Elsensohn, J.E. 2014. EstimateS turns 20: statistical estimation of species richness and shared species from samples, with non $\square$ parametric extrapolation [electronic resource]. Ecography 37: 609-613.

Coulter, E.M. 1955. Wormsloe: Two Centuries of a Georgia Family. University of Georgia Press. Athens, Georgia.

Craft, C., Clough, J., Ehman, J., Joye, S., Park, R., Pennings, S., Guo, H. and Machmuller, M. 2009. Forecasting the effects of accelerated sea-level rise on tidal marsh ecosystem services. Fronteirs in Ecology and the Environment 72(2): 73-78.

Dodd, C.K. and Barichivich, W.J. 2007. Establishing a baseline and faunal history in amphibian monitoring programs: the amphibians of Harris Neck, GA. Southeastern Naturalist 6: 125-134.

Dorcas, M.E. and Gibbons, J.W. 2008. Frogs and Toads of the Southeast. Univeristy of Georgia Press, Athens and London.

Gagne, S.A. and Fahrig, L. 2010. Effects of time since urbanization on anuran community composition in remnant urban ponds. Environmental Conservation 37: 128-135.

Georgia Department Natural Resources. 2010 . Coastal Georgia Vegetation Habitat Map. Nongame Widlife Division, Georgia Department of Natural Resources

Gibson, C.D. 1948chr. Sea Islands of Georgia: Their Geologic History. Athens, University of Georgia Press, Athens, Georgia.

Hoyt, J.H. 1967. Barrier island formation. Geological Society of America Bulletin 78: 1125-1136.
Jensen, J.B., Camp, C.D., Gibbons, J.W. and Elliot, M.J. 2008. Amphibians and Reptiles of Georgia. University of Georgia Press, Athens, Georgia.

Kish, S., Milla, K. and Means, R. 2012. Dynamics of water levels in ephemeral ponds of the Munson Sandhills, lower coastal plain of northwest Florida. Geological Society of America 44: 436-436.

Kushlan, J.A. 1987. External threats and internal management: the hydrologic regulation of the Everglades, Florida, USA. Environmental Management 11: 109119.

Laerm, J., Castleberry, N., Menzel, A., Moulis, R., Williamson, G., Jensen, J., Winn, B. and Harris, M. 2000. Biogeography of amphibians and reptiles of the Sea I slands of Georgia. Florida Scientist 63: 193-231.

McMenamin, S.K., Elizabeth, A.H. and Wright, C.K. 2008. Climatic change and wetland desiccation cause amphibian decline in Yellowstone National Park. Proceedings of the National Academy of Sciences of the United States of America 105: 16988-16993.

Neill, W.T. 1958. The occurrence of amphibians and reptiles in saltwater areas, and a bibliography. Bulletin of Marine Science of the Gulf and Caribbean 8: 1-97.

Nelson, B.R., Reichard, J.S., Meyer, B.K., Vance, R.K. and Bishop, G.A. 2012. Characterizing the surficial aquifer across the Pleistocene core of St. Catherines Island, Georgia. Geological Society of America 44: 60-60.

Noss, R.F., Platt, W.J., Sorrie, B.A., Weakley, A.S., Means, D.B., Costanza, J. and Peet, R.K. 2014. How global biodiversity hotspots may go unrecognized: lessons from the North American Coastal Plain. Diversity and Distributions 21(1/2): 236-244.

O'Hare, N.K. and Madden, M. 2017. Herpetofaunal Inventory of Wormsloe State Historic Site, Savannah, Georgia. Southeastern Naturalist 17(1): 1-18.

Peck, M.F. and Payne, D.F. 2003. Development of an estimated water-table map for coastal Georgia and adjacent parts of Florida and South Carolina. Proceedings of the 2003 Georgia Water Resources Conference. https://www2.usgs.gov/water/southatlantic/ga/publications/.../Peck_Payne-GWRC2003. Accessed December 18, 2017.

Peck, M.F., Painter, J.A. and Leeth, D.C. 2009. Ground-water Conditions and Studies in Georgia, 2006-2007. US Geological Survey: Reston, VA.

Ray, A., Sepulveda, A., Hossack, B., Patla, D. and Legg, K. 2014. Using monitoring data to map amphibian breeding hotspots and describe wetland vulnerability in Yellowstone and Grand Teton National Parks. Park Science 31: 112-119.

Rogell, B., Berglund, A., Laurila, A. and Höglund, J. 2011. Population divergence of life history traits in the endangered green toad: implications for a support release programme. Journal of Zoology 285: 46-55.

Santos, A.M.C., Whittaker, R.J., Triantis, K.A., Borges, P.A.V., Jones, O.R., Quicke, D.L.J. and Hortal, J. 2010. Are species-area relationships from entire archipelagos congruent with those of their constituent islands? Global Ecology and Biogeography 19: 527-540.

Shoop, C. and Ruckdeshcel, C. 2003. Herpetological biogeography of the Georgia barrier islands: an alternative interpretation. Florida Scientist 66: 43-51.

Shoop, C.R. and Ruckdeshcel, C. 2000. Amphibians and Reptiles of Cumberland Island, Georgia: A checklist. Occasional Publications of the Cumberland Island Museum No. 2, p. 8. Cumberland Island Museum, St Mary's, GA. 
Snider, A.T. and Bowler, K.J. 1992. Longevity of Reptiles and Amphibians in North American Collections. Second edition. Society for the Study of Amphibians and Reptiles, Milwaukee, WI.

StatSoft 2014. Statistica 12.0

Tiner, R. 1997. NWI Maps: Basic Information on the Nation's Wetlands. BioScience 47(5): 269-269.

Triantis, K.A. and Sfenthourakis, S. 2012. Island biogeography is not a single-variable discipline: the small island effect debate. Diversity and Distributions 18: 92-96.

Triantis, K.A., Vardinoyannis, K., Tsolaki, E.P., Botsaris, I., Lika, K. and Mylonas, M. 2006. Re-approaching the small island effect. Journal of Biogeography 33: 914-923.

Tuberville, T.D., Willson, J.D., Dorcas, M.E. and Gibbons, J.W. 2005. Herpetofaunal species richness of southeastern national parks. Southeastern Naturalist 4: 537-569.

Vance, R.K., Bishop, G.A., Rich, F.J., Meyer, B.K. and Reichard, J. 2010. Sag structures on St. Catherines Island, Georgia: Implications for barrier island hydrology and coastal water resources. Geological Society of America 42: 147-147.
Vanstory, B. 1970. Georgia's Land of the Golden Isles. University of Georgia Press, Athens, Georgia.

Vitt, L.J. and Caldwell, J.P. 2014. Herpetology : An Introductory Biology of Amphibians and Reptiles. Fourth Edition. Academic Press, Amsterdam and Waltham, MA.

Whitehead, D.R. and Jones, C.E. 1969. Small islands and the equilibrium theory of insular biogeography. Evolution 23(1): 171-179.

Williamson, G.K. and Moulis, R.A. 1979. Distribution of Georgia Amphibians and Reptiles in the Savannah Science Museum Collection. Savannah Science Museum, Savannah, GA.

Williamson, G.K. and Moulis, R.A. 1994. Distribution of Amphibians and Reptiles in Georgia. Savannah Science Museum, Savannah, GA.

Wright, A.H. 1932. Life-Histories of the Frogs of the Okefinokee Swamp, Georgia. Macmillan Company, New York.

Zeigler, J.M. 1959. Origin of the Sea Islands of the southeastern United States. Geographical Review 49: 222237. 